\title{
EXPERTS, POLEMICISTS, DOCTORS, AND DEBUNKERS A TYPOLOGY OF CELEBRITY ECONOMISTS
}

\author{
TATIANA BAJUK SENČAR
}

The author elaborates a typology of celebrity economists in order to examine the nature and role of this particular group of celebrities that operates at the national and international levels. The author presents examples for each category of celebrity economist, for which she analyzes their professional biographies and their spheres of operation and the ways that they operate as public figures in order to map out the diverse social roles of celebrity economists and the roots of their celebrity status.

Keywords: celebrity economists, typology, celebritization, Paul Krugman, Jeffrey Sachs, Yanis Varoufakis
Avtorica predstavi tipologijo slavnih ekonomistov in analizira značilnosti ter vloge te specifične skupine slavnih oseb, ki delujejo na nacionalni in mednarodni ravni. $V$ vsaki kategoriji obravnava izbrane slavne ekonomiste, analizira njihove poklicne poti, kontekste, v katerih delujejo, in načine njihovega delovanja. Razišče tudi različne družbene vloge teh oseb in izvor njihovega zvezdniskega statusa.

Ključne besede: slavni ekonomisti, tipologija, produkcija zvezdnisttva, Paul Krugman, Jeffrey Sachs, Janis Varufakis

Studies of heroes and celebrities and their role in the Slovene public sphere have focused on a broad range of social actors across numerous periods: from the period of Slovenia's nation-building process (Jezernik 2013; Fikfak 2014) to figures from Slovenia’s socialist era (Hudales 2013; Dežman 2013) through to the present day (Komel 2014). Researchers have focused as well as heroic figures in contemporary literature and music (Mursič 2013; Zupan Sosič 2013) and have also focused on the overlaps and distinctions between heroes and celebrities (Podjed 2012; Pletenac 2014; Turkoz 2014). The following study expands this discussion by focusing on one particular kind of celebrity that one can find across cultures and societies in the world today: celebrity economists. As bearers and practitioners of a privileged form of knowledge, economists are accorded a relatively high amount of prestige. Indicators of the value attributed to the economic sphere are numerous and varied, from the ways that economic discourse and concepts have infiltrated everyday speech to a prevalent belief in the economic sphere as a driver of social change. Its importance is also evident in the far-reaching consequences of problems that develop in the economic sphere. Economics is not a theoretical discipline that is developed solely within the confines of the ivory towers of the academy; its practitioners play significant roles in government bodies and institutions active in the daily operation of markets at all levels. It is thus not surprising that economists have attained renown in the public sphere that transcend the boundaries of their discipline.

However, it is not possible to paint all economists with the same brush. There are numerous accomplished and distinguished economists worldwide, and the basis of their 
public recognition can vary - be it their extraordinary university careers, their contributions as researchers to the discipline, as policymakers or as practitioners on the ground. In addition, some of the most powerful economists are those that operate behind the scenes, either in government cabinets or in multilateral institutions; yet, the high-profile nature of such institutions is not linked to the individuals that work in them.

There are also economists known as celebrity economists, individuals with the status of celebrities, virtually household names in the public sphere. In this paper, I present my research on celebrity economists as a social category across contemporary societies in order to examine the range of practices and public presence linked to celebrity economists in diverse contexts. What do celebrity economists working in different societies have in common, what sorts of social actors become celebrity economists, what elements constitute the social formation of celebrity economists? Finally, what sort of celebrity is the celebrity economist?

While most of the economists that are examined in the following pages operate primarily in Western countries (i.e., United States and Europe), the following description of an article in an influential economics weekly points to the global prevalence of celebrity economists and their identification in the public sphere as celebrities. The Economist published a short article on celebrity economists in Argentina, describing the extraordinary high-profile status of economists, citing the surprising popularity of economists in comparison to that of actors and rock stars using the number of Twitter followers as a measure of celebrity. Recently deceased economist Tomas Bulát, who was a bestselling author and host of his own weekly television show on economists boasted over 179,000 followers. Ricardo Darín, one of Argentina's most famous actors, has only 41,000 followers while Andrés Calamaro, a well-known rock star, has only 34,000. However, Martín Redrado, a former head of the central bank who early on in his career once worked with Jeffrey Sachs and who now has his own consulting firm, has 145,000 followers. Martín Lousteau, 45-year old former economics minister, congressman and current ambassador of Argentina to the United States, is also a tabloid celebrity with 240,000 followers on Twitter, who is frequently hounded for autographs. A few years ago, he married Carla Peterson, one of Argentina's top actresses, which also resulted in increasing his status as a national celebrity. ${ }^{1}$

The Economist in its presentation of Argentina's special breed of celebrity economist cites economics professor Victoria Giarrizzo of the University of Buenos Aires to explain their extraordinary popularity: "The Argentine economy is like a sickness. People have to stay constantly informed to manage their personal finances. As bearers of answers in times of chaos, economists have amassed a unique amount of power... Having economists appearing frequently on television and in the newspapers is not a good sign. That means things aren't going so well"'

1 Celebrity Economists: The Sages of the Pampas. The Economist. 29 November 2014. http://www.economist.com/news/finance-and-economics/21635016-tango-fame-argentine-economists-tinged-sadness-sages.

2 See footnote 1. 


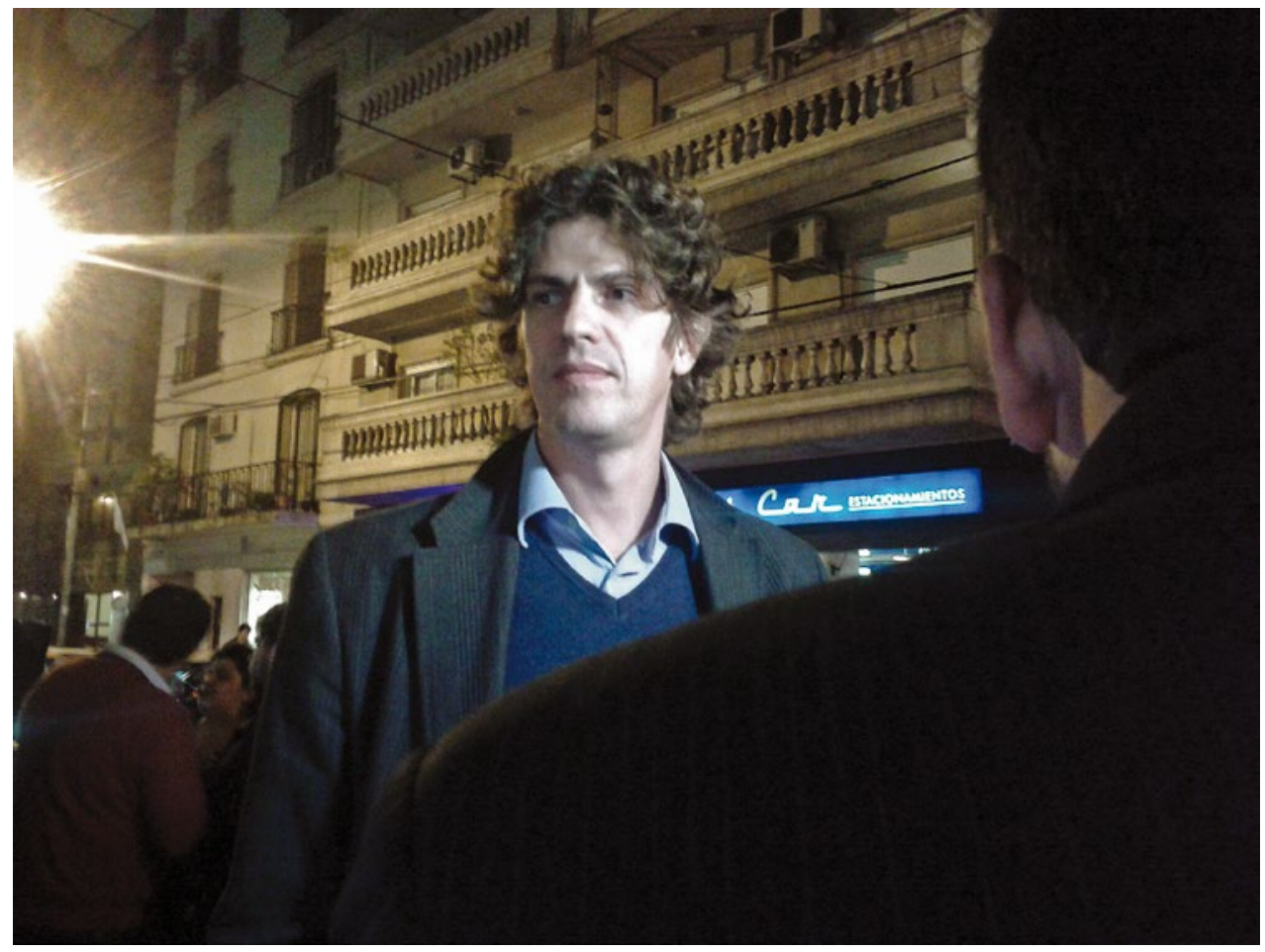

Figure 1: Photograph of Martín Lousteau accosted by photographers as he arrives at a neighborhood meeting sponsored by Argentina’s Broad Front UNEN coalition. Author: Ginés90. This photograph is licensed under the Creative Commons Attribution-Share Alike 4.0 International license.

While there is more than a kernel of truth to this theory, I would argue that it is not that simple. The economists mentioned in this article are very different - one is a popular author and TV host, another is a well-known consultant, and yet another is a politician. The roots of their popularity and authority vary, as do the roles that they play as economists and as public figures. Just as the category of economist is not itself a monolithic category, neither is that of celebrity economist. In this article, I present a range of profiles of celebrity economist in order to examine the social category of celebrity economist in more detail. I focus on one person for each profile that I identify, and in mapping out their career histories, I will analyze the roots of their recognition as economists, their realms of operation, and their role in the public sphere.

In approaching celebrity economists as a social category I wish to place some analytical distance between economists' role as celebrities and the socially powerful views that economists ascribe to and disseminate in the function of social explanation. It is important to note that the reason that The Economist offers in light of the economists' massive popularity in Argentina - greater than that of „regular“" celebrities such as actresses or rock stars - comes in the form of an economic explanation offered by an economics expert, an economics professor. The social popularity of economists is linked to the state of Argentina's economy: 
as the state of the economy gets worse, the popularity of economists rises as those with the expert knowledge presumably capable of getting a crisis situation back under control or disseminating expert advice to a broader public. The fact that this view is propagated as a valid explanation is evidence of the social power of economic discourse as well as this discourse's self-referentiality, which links economists' popularity to economics as a form of specialized knowledge.

While the distinctiveness of celebrity economists as a breed of present-day celebrities is based in large part on their role as experts, an explanation for the rise and popularity of celebrity economists such as the one cited above does not take into account the social dimension of celebrity nor the range of practices and processes through celebrity identities are formed and maintained. In this article, I look to existing analyses within celebrity studies to identify the questions and issues that structure the categorization of existing celebrity economists.

The existing lines of inquiry that compile the interdisciplinary field of celebrity studies have made great strides in understanding the place of celebrities and of celebrity making in social life. In particular, researchers have helped map out the contours and the distinctive nature of celebrity as a category and social role both in the past and the present. Researchers such as Fred Inglis (2000), have contributed to mapping out the shift in the criteria that shape what he termed „the business of renown and celebrity“ (Inglis 2000: 3) over the last two centuries, with renown once attributed to accomplished men (primarily) in prominent roles or offices. Inglis links the development of celebrity to a shift in these criteria and the development of the urban spectacle in the form of urban leisure spaces - be they theaters, concert halls, pleasure gardens, coffee houses, or wide city boulevards. Men and women of renown were no longer identified by their accomplishments or their privileged positions but by their visibility in social life that played out in such spaces. ${ }^{3}$ Developments of this kind led to the rise of celebrities as persons who, to paraphrase Daniel Boorstin, are known for being famous (Boorstin 1992).

Analysts whose work falls within the boundary of celebrity studies have focused on various issues in addition to the history of celebrity, including the nature of stars or celebrities (Dwyer 1979, 1986; Rojek 2001); the significance of celebrities in contemporary culture (Couldry 2009); the consumption of celebrity (Gamson 1994; Hill 2007); the study of different kinds of celebrity (Andrews and Jackson 2001; Whannel 2001); and the broader role of celebrities in social life (Brockington 2014; Kellner 2010). Many researchers working in celebrity studies thus agree that the reasons for being accorded celebrity status do not reside in an individual's accomplishments (Holmes and Redmond 2010) but in the way said individual is represented in the public sphere. The fact that there no longer is a direct link between traditional accomplishments and renown has resulted in celebrity being

3 See Holmes (2008), Murray (2005), and Ponce de Leon (2002) for more work on the history of celebrity. 
cast in a less favorable light, with analysts debating the differences between various shades of renown - including fame, celebrity and notoriety, to name a few - and the criteria or conditions needed to achieve these different social statuses (Epstein 2005).

The celebrity studies mentioned above have helped me shape the questions that have framed my approach to the study of celebrity economists as celebrities. In addition, my research is also inspired by those analysts who have focused on the production of celebrity or celebritization (including Driessens 2013; Kotler, Rein and Stoller 1997; Turner et al. 2000) and on identifying and analyzing the actors, institutions and processes that help produce and maintain celebrities. The question of the production of celebrity economists - including their identification, their formation, and their operation - involves determining the different criteria that distinguish celebrity economists from other economists, the processes and actors involved in their cultivation as a particular brand of public figure, and the diverse public spheres in which they operate as the role of celebrity economist. For example, what distinguishes a celebrity economist from, for example, an economist who is an academic celebrity? Regardless of their field, academics invariably draw a distinction between those academics who have distinguished themselves, who are good at their field, and those who have attained the status of academic celebrities. The criteria, the points necessary to attain one status vis-à-vis the other, may overlap to some degree but also diverse in significant ways. Attaining the status of academic celebrity may be viewed in certain academic circles as relatively suspect, as becoming an academic celebrity does not necessarily celebrate "true" academic achievement as defined within individual fields of knowledge but instead is based on gaining the proper amount of attention from relevant sources and in relevant media. As Epstein argues: "Pure scholarship, sheer power of intelligence glowing brightly in the classroom, is distinctly not what makes an academic celebrity or, if you prefer, superstar. What makes an academic celebrity, for the most part, is exposure, which is ultimately publicity" (Epstein 2005: 16). However, the fact that the distinction between achievement and celebrity in the academic world may be strongly marked and framed in terms of publicity does not take away from the fact that both sets of criteria are socially defined. Does academic achievement really reflect "pure" scholarship, as Epstein depicts above? Academics across all fields would admit to the existence of a gradation of criteria according to which academic achievement is also assessed (publishing in the proper journals, attaining the proper sort of funding, going to the proper conferences, etc.). In the following set of profiles I identify the features that distinguish different categories of celebrity economists by paying close attention to the factors that facilitate their production and operation. What are the factors that characterize celebrity economists? 


\section{PIONEER CELEBRITY ECONOMIST: IRVING FISHER}

One of the first persons to be identified as a celebrity economist was Irving Fisher, an American economist, statistician, inventor, and Progressive social campaigner. Economist Joseph Schumpeter described him as ,the greatest economist the United States has ever produced" (Schumpeter 1951: 223). Fisher was also one of the first American economists: he attended Yale College, where was the first person to receive a Ph.D. in economics from Yale in 1891. After spending some time in Berlin and Paris - where at that time economics was a more developed discipline - Fisher returned to Yale, where he built his academic career. As one of the first economics professors in the US, Fisher was also a central figure in the field of economics and its early development in the US. He became president of the American Economic Foundation in 1918, was an early proponent of econometrics. He founded the Econometrics Society together with Ragnar Frisch and Charles Roos and was later also the society's first president (Tobin 2005: 19). Fisher also contributed to the development of the discipline by authoring numerous books and articles. However, it is not only his being a prolific writer that distinguished him among his peers, but also his writing style, as is apparent from the following excerpt:

Irving Fisher was one of America's greatest mathematical economists and one of the clearest economics writers of all time. He had the intellect to use mathematics in virtually all his theories and the good sense to introduce it only after he had clearly explained the central principles in words. And he explained very well. Fisher's Theory of Interest is written so clearly that graduate economics students can read - and understand - half the book in one sitting, something unheard of in technical economics. ${ }^{4}$

His work in developing the field of economics was an important contributing factor to his becoming an academic celebrity, if not a celebrity economist. In the early $20^{\text {th }}$ century, Fisher was among most cited economists in the world (Dimand and Geanokoplos 2005: 3-4). Yet, it was his activities outside the realm of the economic discipline that helped him attain the title of celebrity economist. Fisher fell ill with tuberculosis early in his career. While he was cured of the disease, he maintained a lifelong interest in health issues and become a social activist, campaigning and writing for health issues as well as advocating vegetarianism and the prohibition of alcohol. He was also a successful inventor, and his inventions - together with his stock investments - made him a wealthy man.

He also exercised his role as a celebrity economist by issuing public statements; however, one of his statements provided a fatal blow to his reputation when he stated that the

4 „Irving Fisher." The Concise Encyclopedia of Economics. 2008. Library of Economics and Liberty. 22 January 2016. <http://www.econlib.org/library/Enc/bios/Fisher.html>. 


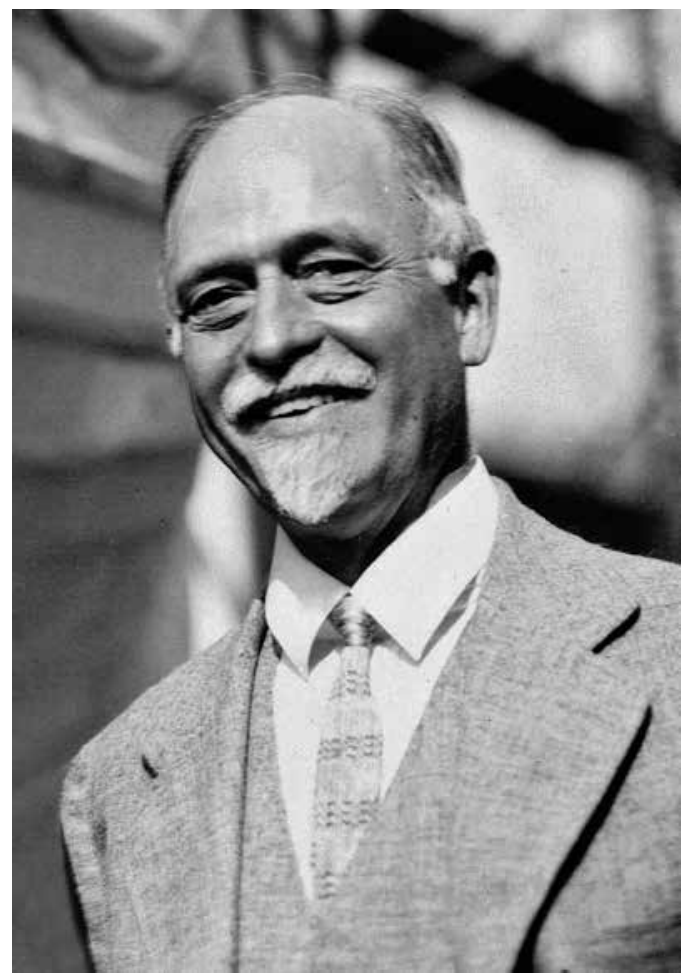

Figure 2: Photograph of Irving Fisher. George Grantham Bain Collection, Libaray of Congress. reproduction number: LC-USZ62-101512.

stock market in the US had reached "a permanently high plateau" just prior to the Wall Street Crash of 1929 (Economist 2009). His reputation and professional standing suffered because of his misguided statements, as did his personal finances. It was only in the 1950s, approximately 15 years after his death that his work was rediscovered and he was recognized in as one of the earliest American neoclassical economists. In addition, his work has been recognized as newly relevant, both within the public media and economic (academic) circles, in light of the recent global economic crisis ${ }^{5}$ (Dimand and Geanokoplos 2005).

As a pioneer in a growing discipline who occupied a top-level position at an elite university, Fisher helped set the standards for economics as experts in numerous ways - from choosing key topics and methodologies to defining the roles that economists could play in public life. He played an important role as an economist who also employed his professional knowledge and prestige to accumulate personal wealth as well as disseminate economic and financial advice beyond the boundaries of economics as a community of knowledge. In addition, he was able to capitalize on his professional and public prestige to operate as a commentator on broader social issues that were important to him - such as the prohibition of alcohol and the dangers of smoking tobacco - by writing in popular magazines such as the Reader's Digest (Fisher 1924). His activities as a successful inventor added to his public image of celebrity expert. However, this sort of celebrity outside the academic sphere backfired on him during the course of his career, with catastrophic consequences for him both professionally and personally. It was only decades after his death that his professional reputation was restored. His experience operates as a cautionary tale concerning the difference between making a mistake in predicting economic trends in theory and in practice.

5 Irving Fisher: Out of Keynes's shadow. The Economist. 12 February 2009. http://www.economist. com/node/13104022 


\section{THE CELEBRITY ECONOMIST AS PUBLIC INTELLECTUAL: PAUL KRUGMAN}

Irving Fisher as a pioneer celebrity economist was able to take on numerous roles in the public sphere - from economic expert to inventor to social commentator. As a well-known figure who could speak out on numerous issues and disseminate his position in a range of public media, Fisher was also the precursor of the celebrity economist as public intellectual: that is, an economist who is able to take on an expert role far beyond the boundaries of economic community in order to advocate positions on a range of topics.

Economist Paul Krugman can be considered one of the most well-known celebrity economists operating as a public intellectual today. However, he become a celebrity econo$\mathrm{mist} /$ public intellectual rather late in his professional life, after building up an extraordinary academic career. He received his B.A. degree in economics at Yale University and his PhD from the Massachusetts Institute of Technology (MIT) in 1977. Upon receiving his PhD, he remained at MIT as a faculty member and became a full professor in seven short years, by 1984 . He remained at MIT through the year 2000, with brief hiatuses to work briefly for US President Ronald Reagan's Council of Economic Advisors and to teach at Stanford University. Until recently, he was Professor of Economics and International Affairs at Princeton University and Centenary Professor at the London School of Economics. In the second half of the year 2015, Krugman became an economics professor at the City University of New York's Graduate Center and a distinguished scholar at the Graduate Center's Luxembourg Income Study Center.

In addition to having developed an enviable academic career, Paul Krugman is also a long-standing research associate at the National Bureau of Economic Research (NBER), the US's leading nonprofit economic research organization. He is also a member of the Group of Thirty (G30), an international economic body of leading financiers and academics from around the world focused on improving the understanding of economic and financial issues and current trends.

Save for a brief period during which he worked for the Reagan administration in the early 1980s, Krugman's career comprised teaching and conducting research, the results of which were published in almost 20 books during the course of his career and over 200 scholarly articles in professional journals and volumes. He is known for primarily his work on international economics, (including trade theory, economic geography and international finance), liquidity traps and currency traps. He has received numerous awards in recognition of his contributions to economic thought, particularly his work on international trade and economic geography. The most significant honors he received include the John Bates Clark medal awarded to economists under the age of 40 in 1991 and the Nobel Prize in Economics, which he received in $2015 .^{6}$

6 "Paul Krugman: American Economist" Encyclopedia Britannica. accessed 22 January 2016 http:// www.britannica.com/biography/Paul-Krugman 


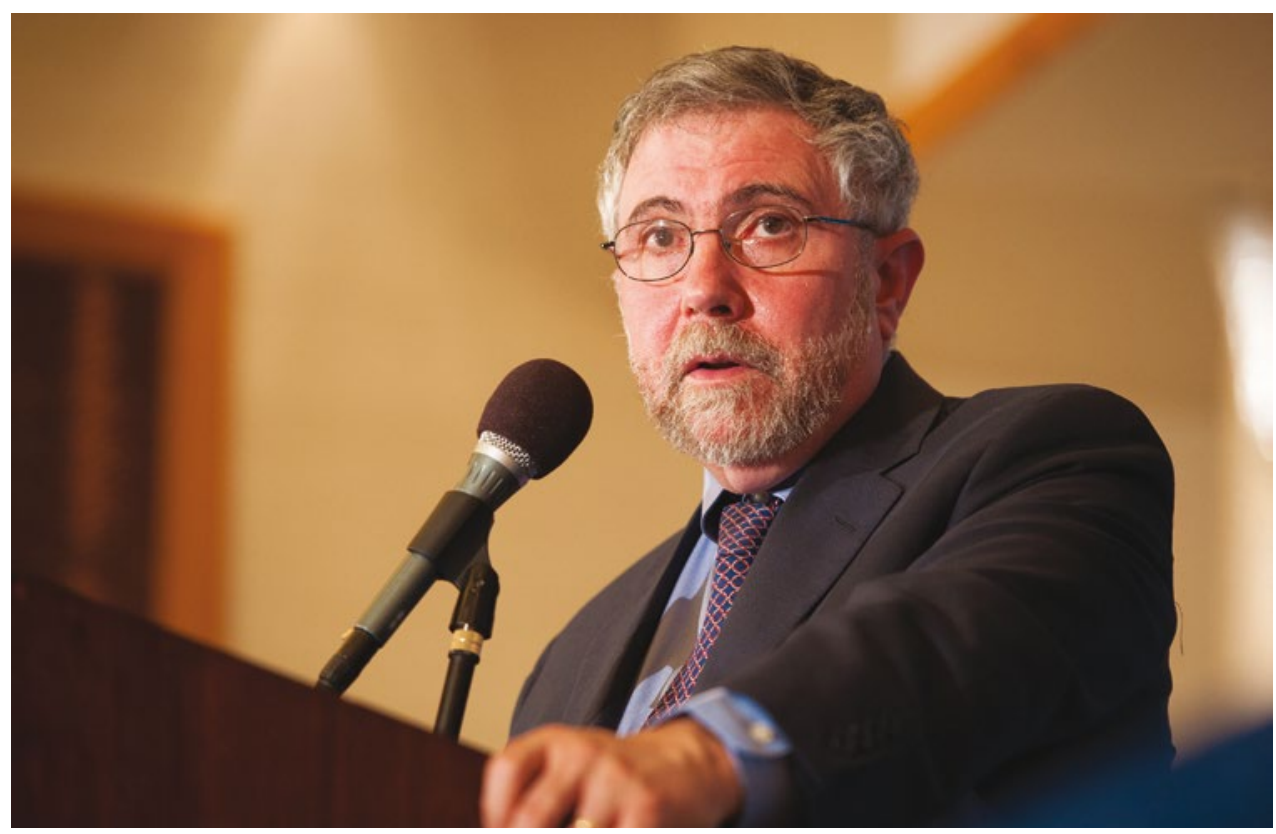

Figure 3: Photograph of Paul Krugman speaking at the Commonwealth Club of California, in San Francisco. May 22, 2012. Photo by Ed Ritger. Creative Commons Attribution-Share Alike 2.0 International license.

Yet it was Krugman's clear and prolific writing style both inside and outside the economic sphere that contributed to his becoming a public intellectual. Economist J. Peter Neary notes that Krugman "has written on a wide range of topics, always combining one of the best prose styles in the profession with an ability to construct elegant, insightful and useful models...no discussion of his work could fail to mention his transition from Academic Superstar to Public Intellectual. Through his extensive writings on economics and current affairs for the general public ... he has probably done more than any other writer to explain economic principles to a wide audience" (Neary 2009).

Krugman began writing for a broader audience in the 1990s with his first popular book titled The Age of Diminished Expectations and with regular columns in the magazines Slate and Fortune in the mid-1990s (Krugman 1994). It was however his role as an op-ed columnist in the New York Times that played a crucial role in his becoming a public intellectual. He has written over 750 articles on economic and political issues for the New York Times as well as other magazines such as The New Republic, Foreign Policy, Newsweek, and even Rolling Stone. His standing as one of the most influential economic thinkers, as per a poll organized by the Economist in $2015^{7}$ (Economist 2015), is due in great part to his prolific writing for a more general audience and in numerous media.

7 Influential Economists: Shifting Clout. The Economist. 3 January 2015. http://www.economist.com/ node/21637412/print 
Krugman's role as an influential public intellectual is based to great extent on the quantity of his economic writing for a popular audience and the range of public media in which his writing appears; this is due in part to his professional prestige that helped him acquire the position of regular columnist in public media with global reach. It is also due to the fact that he writes as a political commentator as well as an economic one.

As a self-described liberal and primarily a Keynesian economist, Krugman's comments on a range of issues do not fall in line with the (neoliberal) norm, and he has employed his comments in the broader public sphere to draw attention to, praise or criticize policies in an effort to effect change. His comments extend beyond the scope of economics - including themes from the $9 / 11$ attacks to US race relations to issues of a global scale, which is not surprising given that one of his fields of expertise is international trade and finance. In addition, while his position on many issues seemed to fall consistently on one side of the political divide in the American public sphere - on the side of the Democrats - his critical views often do not respect party lines but address issues independently of party affiliations. While he began writing to a general public from a strictly economic standpoint, his pieces have taken ever stronger political overtones over the years in response to current events both economic and political, primarily those unfolding in the United States.

Krugman's transition to economic and political commentator is also due to to his belief that the political often determines the economic, rather than the other way around. For example, Krugman in his work The Age of Diminished Expectations argues that the growing increase in inequality is due primarily to political factors - including political decisions on taxation and unions (Krugman 1994). However, many of the issues that he engages are both politically and economically controversial - at least, not in line with the neoliberal norm - which has led to what many commentators describe as the radicalization of Krugman's writing for a general public. According to journalist Michael Tomasky, Krugman has been moving „from being a center-left scholar to being a liberal polemicist” from 1992 onwards (Tomasky 2007). Larissa MacFarquihar argues that Krugman's radicalization as a public commentator began around the year 2000:

It was the 2000 election campaign that finally radicalized him. He'd begun writing his column the year before, and although his mandate at the outset was economic and business matters, he began paying more attention to the world in general. During the campaign, he perceived the Bush people telling outright lies, and this shocked him. Reagan's people had at least tried to justify their policies with economic models and rationalizations. Krugman hadn't believed the models would work, but at least they were there. After the election, he began to attack Bush's policies in his column, and, as his outrage escalated, his attacks grew more venomous. Krugman felt that liberals were unwilling to confront or even to acknowledge the anger on the right with some of their own, so he was going to have to do it. Krugman attacked Bush for trying to bankrupt Social Security, 
for promoting an economically and environmentally disastrous energy policy, for increasing inequality by cutting taxes for the rich and corporations, for using the war on terrorism to conceal his fiscal misdeeds, and for insider trading before he became President. He wrote a brave column on September 16, 2001, arguing that the catastrophe of September $11^{\text {th }}$ was partly self-inflicted, because the government had abandoned airport security - which should be a public service-to be paid for by the airlines, who naturally did it on the cheap (MacFarquihar 2010).

Krugman has only developed this critical stance further over time and has addressed issues and questions from the perspective of a liberal economist regardless of party lines, rendering him a controversial yet extremely popular commentator. It is thus Krugman's relatively strong presence in influential public media and his broad role as an independent public figure - one that extends beyond that of "scholar" - that categorizes him as a celebrity economist or public intellectual.

\section{THE CELEBRITY ECONOMIST AS GLOBE-TROTTING DEVELOPMENTAL CONSULTANT: JEFFREY SACHS}

Economists who are public intellectuals are often offered formal or informal roles as advisors or consultants contributing to the development of economic policies. In this manner, they can get their hands "dirty" in the "real" world as opposed to publicly offering their opinion in diverse media from the comfort of their armchairs. Celebrity in one sphere may often lead to celebrity in another, and thus economists of a certain level of renown assume multiple posts. The majority of such actors, however, work primarily out of one context. Yet, there is a group of economists who are inherently mobile and whose global reach is a result of their working on the ground in numerous countries as expert consultants, be it to governments or to institutions. Jeffrey Sachs is the quintessential celebrity economist in this category.

Even among the world's elite economists, Jeffrey Sachs meteoric rise to fame is extraordinary. Sachs exhibited his gift for mathematics at a relatively young age, taking college-level math courses before even starting secondary school. Sachs enrolled in Harvard University to study economics both at the undergraduate and graduate levels. When he completed his Ph.D., he was immediately offered a faculty position. Two years later, he became a full professor of economics with tenure at the young age of 28 (Munk 2007). Only French celebrity economist Thomas Piketty, who received his award-winning $\mathrm{PhD}$ at the age of 22 and became professor at EHESS (École des hautes etudes en sciences sociales) at age 29, has had a similarly meteoric academic trajectory (White 2016).

Sachs started out as professor of international trade at Harvard, but soon became director of the Harvard Institute for International Development, and, a few years later, 
director of Harvard's Center for International Development. He is presently director of The Earth Institute at Columbia University as well as the Quetelet professor of Sustainable Development and Health Policy and Management. ${ }^{8}$

His transition to a faculty position in the field of international development is a logical result of his extensive work as an economic advisor to governments of developing countries in Latin America, transition countries in Eastern Europe and the former Soviet Union, developing countries in Asia, and, finally, developing countries in Africa. His introduction to this kind of work has virtually assumed the level of myth and is linked to Sachs having established himself as an authority on inflation and international finance. In 1985, Bolivia had developed a case of hyperinflation of 25,000\% annually. During a seminar at Harvard on the Bolivian crisis organized by some Latin-American students, Sachs interrupted the speaker, strode to the blackboard, and announced, "Here's how it works." A voice at the back of the room then said, "Well, if you're so smart, why don't you come down to La Paz to help us?" Sachs laughed, but seven weeks later, Sachs arrived in La Paz to help implement an austerity plan that included huge cuts in government spending, massive layoffs of state employees, a complete overhaul of the tax system, and, above all, an abrupt shift to a market economy, a set of measures often referred to as shock therapy. While these measures had numerous effects, both positive and negative, they did manage to reduce the country's inflation down to annual rate of 15\% (Cassidy 2005).

Sachs's role in Bolivia rendered him an international celebrity overnight, and upon the heels of the reduction of hyperinflation, Jeffrey Sachs was asked to offer advice to numerous countries around the world. A journalist in the New York Times describes the sort of lifestyle that exemplifies the global reach of his role as a celebrity economist and development consultant:

With outspoken views and a penchant for third world countries, the 34-year old Harvard economist finds adventures wherever he goes. Last week, his presence was felt here throughout the annual Monetary Fund meetings. On Wednesday, he was at the Polish embassy, where officials of the Solidarity-backed government unveiled an economic plan to "shock" Poland into free-market reforms - a plan that Mr. Sachs helped devise. The same day, he appeared on a panel and jousted with world bankers over the Mexican debt plan. The day before, he met with the President of Venezeula in New York (Wayne 1989).

However, this newfound popularity did not necessarily imply celebrity in the positive sense of the word. The self-confidence that he displayed at the Harvard seminar long ago extended also to his reform plans, despite the fact that they are highly controversial. His

8 Jeffrey Sachs: American Economist. Encyclopedia Britannica. accessed 17 February 2016. http://www. britannica.com/biography/Jeffrey-D-Sachs 
plans, though simple, were often drastic in that they were based on massive change. The dramatic nature of his economic prescriptions are also projected on him personally in the public media, and he was often described as young, brash and flamboyant - all characteristics that earned him the moniker of "the Indiana Jones of economics" (Risen 1990). However, the controversy that surrounded him was also due to the fact that he advocated that poor countries' foreign debt be pardoned, a position that did not ingratiate him to the Western banking establishment (Wayne 1989).

As mentioned above, Sachs was asked to consult in numerous post-socialist transition countries in the early 1990s, including Poland, Russia, and, albeit briefly, Slovenia. Sachs's work with fellow Harvard economist David Lipton in Poland resulted in the Sachs-Lipton plan that was set in motion in early 1990. This plan accorded Sachs a central role in the massive controversy that played out in numerous post-socialist governments, policy committees, and academic circles about the best way to engineer the transition from socialism to capitalism. One example of this was Sachs' role in shaping the stormy controversy surrounding privatization in Slovenia, which was structured by the proposal of two very different privatization models. One was proposed by Slovene economist Jože Mencinger, who as vice-president of the Slovenian government advocated a privatization model based primarily on manager buyouts. Jeffrey Sachs and David Lipton helped prepare an alternative model that was based on the distribution of privatization certificates to all Slovene citizens. There was of course a level of the controversy that was based on content, i.e., what sort of model would be most appropriate to effectively implement the privatization process. However, a very large portion of the controversy was focused on the persons who were most strongly identified with each of the models: Jože Mencinger with the "reddirectors", and Jeffrey Sachs with the "Chicago Boys" model of neoliberalism (Mencinger 2008; Kovač 2010). Sachs's role as a globetrotting consultant was thus a controversial one not only in the sphere of practice but that of sphere of opinion, according him an almost unprecedented level of celebrity at a time of great change. Furthermore, as is apparent from the dates of the articles cited above, Sachs is still invoked as a crucial figure that personified the controversies concerning privatization decades after his role in Slovenia's privatization debates came to a close.

From the mid-1990s onwards, Sachs shifted his focus from post-socialist governments to extreme poverty and sustainable development in Africa. He has worked in more than two dozen African countries promoting smallholder agriculture, calling for strengthening primary health systems to aid in breaking the so-called poverty traps. He argues with the right policies and interventions, extreme poverty - defined as living on less than a dollar a day - can be eradicated. A key element of his strategy involves raising development aid to nearly 200 billion by 2015, a strategy that he has outlined in his book titled The End of Poverty (Sachs 2005). His work in Africa is not limited to prescribing change but also extends to implementing it. He is director of the United National Millenium Villages Project, which is being carried out in ten African countries and covers more than 500,000 
people. This project is aimed at implementing an integrated rural development plan that involves working on various fronts - from the increase of agricultural production to the decrease in child mortality rates.

Sachs's role in Africa is not that of the international expert working at a national scale, as was the case in Latin American and in post-socialist countries. In this most recent case, Sachs moved beyond his traditional sphere of celebrity/advisor practices - which often involved operations as the national level garnered worldwide attention and renown. Instead, he extended his operations in diverse directions in order to raise awareness about the causes he advocates, including working at the local level to help implement a UN project being carried out at the level of individual villages. In addition, Sachs has extended his efforts to cultivating and invoking his celebrity to network, lobby, and raise support for his programs in numerous ways. On the one hand, he works with high-profile programs sponsored by the UN and the World Health Organization, which have strong reputations for their development work in Africa. On the other hand, he meets frequently with foreign dignitaries, heads of state and international figures to lobby for funds and other forms of aid. Sachs himself describes his job is to be "a pest" and Mark Malloch Brown, formerly deputy-secretary general of the UN, described Sachs, as a "magnificent battering ram" (Munk 2013). In addition, Sachs has allied himself with another breed of celebrity, celebrity advocates: media stars who employ their celebrity to further a particular cause, normally a philanthropical one (Brockington 2014). In fact, Sachs has been so successful in his efforts to link himself to celebrity-advocates that he is no longer dubbed „Dr. Shock“ but „Bono's guru" instead, in light of his public collaboration with U2's famous lead singer, who also wrote the introduction to Sachs' bestselling book The End of Poverty.

Sachs' celebrity in the first half of his career is based on his having effectively built upon his academic recognition to become an international policy star due to his being personally identified with a controversial but extremely influential austerity program known the world over. In Africa, he continues working as a consultant but also expanded his sphere of operation. His notoriety and global reach accord him access to elite economic actors and institutions that he endeavors to mobilize for his cause. In addition, his status as a global economic celebrity allows him access to other, more popular sectors of the public sphere. However, Sachs' global celebrity is also covered in more popular media where economists rarely appear - such as the glossy magazine Vanity Fair that normally covers the worlds of fashion, food, film, theatre, literature, beauty and travel but also publishes pieces with more "serious" content such as a long interview on Sachs centered on the range of his activities focused on combating extreme poverty. He still remains a very controversial figure, whose policies in Africa garner a great deal of criticism from development experts (Easterly 2006; Munk 2009), a fact that also contributes to his particular brand of renown. 


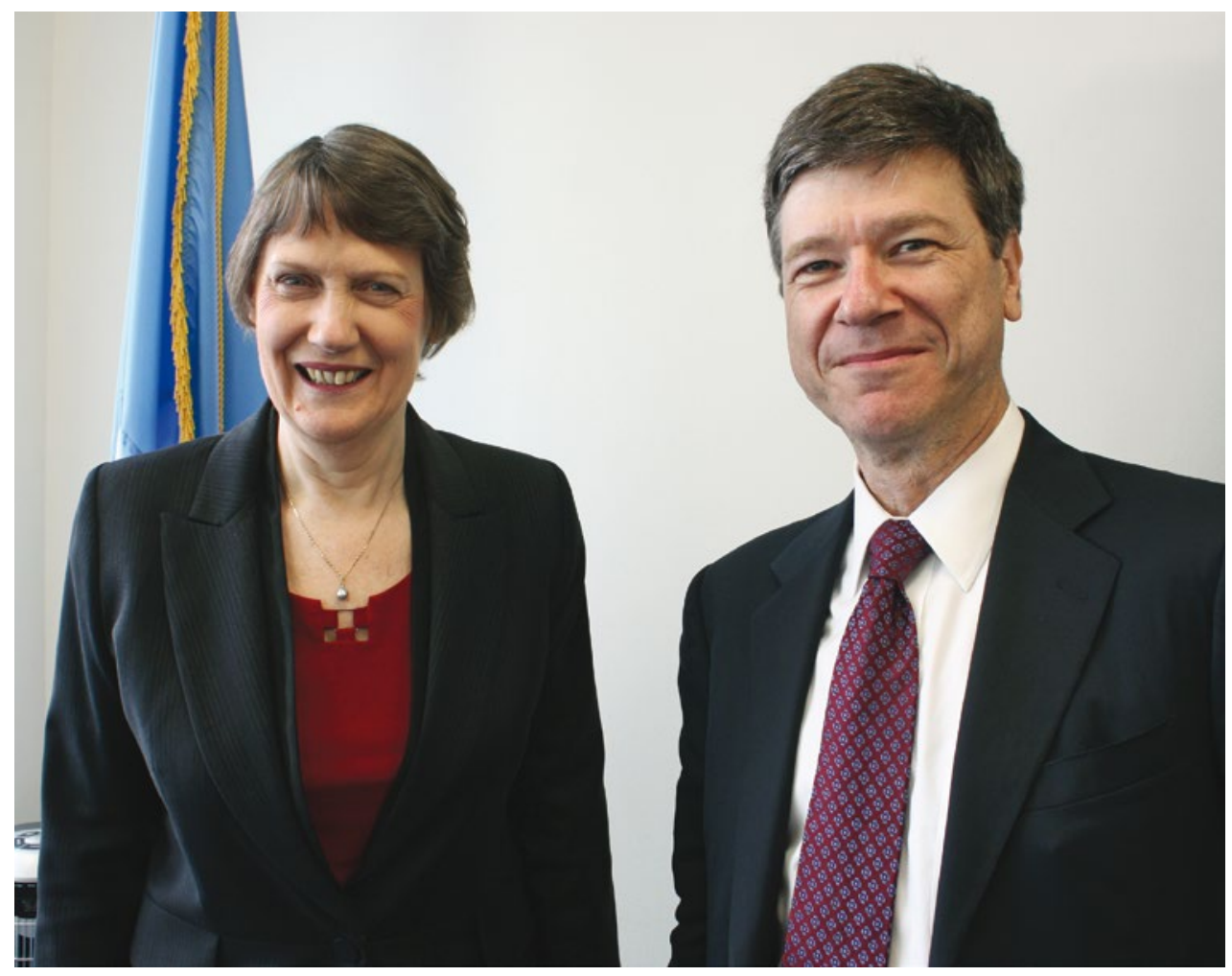

Figure 4: UNDP (United Nations Development Programme)Administrator Helen Clark and Jeffrey Sachs in his role as special Advisor to United Nations Secretary-General Ban Ki-moon, at UNDP headquarters in New York. By Maureen Lynch - originally posted to Flickr as UNDP-USA-126-HR-09, CC BY 2.0, https://commons. wikimedia.org/w/index.php?curid=9508084

\section{CELEBRITY ECONOMIST AS REFORM OR CRISIS ECONOMIST YANIS VAROUFAKIS}

One of the questions that comes to the fore when analyzing the social and economic role of celebrity figures such as Jeffrey Sachs is that of controversy. How does controversy help or hinder an economist's level of celebrity and can he or she cultivate controversy - and the attention that controversy entails - for particular ends? Furthermore, what sorts of controversy influence an economist's renown? Controversy can result from significant policy debates - such as the debates concerning effective development policies in the Third World or those concerning the differences between shock therapy and gradualist transition reforms in which Jeffrey Sachs was embroiled. In his case, the fact that he was and still is involved in implementing reforms that are inherently contested only increases his renown, whether it be the positive or negative sense. Controversy can also arise when a social actor is operating in a historical moment during which actions can take on additional significance. 
This often comes to pass during periods of economic crisis, at which time the choice of action taken to address such a situation is often highly contested. Finally, controversy may also be built into certain roles that economists can assume during certain periods of time.

The final breed of celebrity economists that I address comprises a rather heterogenous category whose public roles often entail being embroiled in controversy: reform or crisis economists. Their celebrity is due in great part to the nature of their activities during periods of great upheaval or the positions that they have at the time of great change. Yanis Varoufakis, an economist whose dramatic and controversial role as Greece's finance minister for a few short months rendered him one of the key figures of 2015 (Addley 2015), is a quintessential crisis celebrity economist.

Yanis Varoufakis was born in Athens, Greece in 1961 but began his career path as an economist in Great Britain. Greece's military junta was still in power when Varoufakis completed his secondary schooling, so his parents deemed it safer that he continue his studies in Great Britain. His university studies took him full circle as regards economics, and this path also defined the sort of economist that he became, critical of the mainstream positions and practices of the discipline.

My initial urge was to study physics but I soon came to the conclusion that the lingua franca of political discourse was economics. Thus, I enrolled at the University of Essex. /.../ However, within weeks of lectures I was aghast at the content of my textbooks and the inane musings of my lecturers. Quite clearly economics was only interested in putting together simplistic mathematical modules. Worse still, the mathematics utilised was third rate and consequently, the economic thinking that emanated from it was atrocious. In short shrift I changed my enrollment from the economics to the mathematics school, thinking that if I am going to be reading mathematics I might as well read proper mathematics. After graduating from Essex, I moved to the University of Birmingham where I read toward an MSc in mathematical statistics. /.../ While looking for a thesis topic, I stumbled upon a piece of econometrics /.../ that angered me so much with its methodological sloppiness /.../ that I set out to demolish it! That was the trap and I fell right into it. From that moment onwards, a series of anti-economic treatises followed, a $\mathrm{PhD}$ in ... economics and a career exclusively in economic departments...?

In his autobiographical blog, Varoufakis describes his role as that of a debunker, or even as an atheist among theologians. Varoufakis began his academic career as an economics professor in the UK - teaching at the University of Essex, the University of East Anglia

9 Varoufakis, Yanis. Beginnings: From the dictatorship of the Colonels to the tyranny of economics. Yanis Varoufakis: Thoughts for the post-2008 world. http://yanisvaroufakis.eu/about/ Beginnings-from-the-dictatorship-of-the-colonels-to-the-tyranny-of-economics/ 
and the University of Cambridge - and then continued his career in Australia, where he was known for being a popular lecturer, particular in his specialty of game theory at the University of Sydney. After spending 12 years in Australia, he moved to Greece in 2000 to teach economic theory at Athens University, where he established the University of Athens Doctoral Program in Economics, which he directed until 2008 (Barber and Hope 2015). His career then developed in a new direction when he moved to the United States in 2012 to become Economist-in-Residence at Valve Corporation, a video game developer and digital distribution company, where he was able to apply his expertise in gaming theory in a new sphere. He remained in the United States as a visiting professor at the University of Texas at Austin through 2014.

Varoufakis' role as an economist outside the academic sphere in Greece began in 2004, when he served as an economic advisor to PM George Papandreou, who was then leader of the parliamentary opposition (Mackenzie 2015). At that time, Varoufakis also began to play a more public role, writing pieces about current economic affairs both at the national and global levels, including the economic crisis, which was the main theme of his popular blog titled 'Yanis Varoufakis: thoughts for the post-2008 world. ${ }^{10}$ Varoufakis emerged as a significant commentator on the economic crisis, collaborating with colleagues both in Greece (Varoufakis, Halevi and Theocarakis 2011; Varoufakis 2011) and beyond its borders, including, Stuart Holland and James K. Galbraith, with whom he published an economic strategy for overcoming the euro crisis (Varoufakis et al 2010).

His extensive comments in diverse media were the platform for disseminating his distinctive position on the Greek crisis, which did not overlap with the official position of the Greek government of the time, that of Greek's creditors or the EU institutions, whose position was to provide additional loans to Greece on the condition of austerity measures. Varoufakis instead argued that the Greek economy had imploded in 2010 when the Greek government could no longer service its debt and that Greece had become insolvent in 2010. In his mind, the official strategy of loans for austerity would simply lead to deeper bankruptcy, depression and further default. In this manner, Varoufakis became a strong voice of opposition to mainstream bailout strategies. ${ }^{11}$

Varoufakis' career took a significant turn when he decided to run for office during the 2014 national elections, in which he won the largest number of votes of any Greek MP, a result that was in itself an indicator of his visibility and popularity. He was appointed finance minister in the new left-wing government of Prime Minister Alexis Tsipras, head of the Syriza party, which had been voted into power on an explicit anti-austerity measure platform. (Christides 2015). The new government assumed office in late January of 2015 and had to negotiate an extension on its loan agreements, which were going to expire in less than a month. Varoufakis was thus thrust into the global spotlight as one of the key

10 Varoufakis, Yanis. Yanis Varoufakis: thoughts for the post-2008 world. http://yanisvaroufakis.eu

11 For links to all his posts related to the Greek crisis, see http://yanisvaroufakis.eu/greek-implosion/. 
actors that would determine the progress of Greece's negotiations with its lenders and those who defined the terms of any aid: the European Central Bank, the International Monetary Fund and the European Commission, otherwise known as the troika.

Varoufakis' celebrity during this period was only enhanced by his well-known views on Greece's financial crisis and on what he considered to be the appropriate ways to address Greece's financial situation. These overlapped with the ruling Syriza party but clashed strongly with that of Greece's lenders and the troika. Varoufakis was thus at the center of the controversies surrounding Greece's bailout not only at the level of political and academic debate but also at the level of highly contested policy. The image of the academic debunker that Varoufakis cultivated extended to the sphere of political practice, as is apparent from the ways in which Varoufakis is depicted in the media. During his time as finance minister, Varoufakis was described as a maverick, as controversial, confrontational, and charismatic (Christides 2015; Smith 2015). His often brash comments that likened austerity measures to "fiscal waterboarding" and "terrorism" gained him instant celebrity, almost rockstar status among certain publics but alienated others (Addley 2015). Many media depictions of him projected his personality features and his controversy onto physical depictions of him that focused on his physical appearance, his clothing style and his choice of personal transportation. They paint an altogether unconventional image of a finance minister: a leather-jacket-wearing, anti-austerity motorbiker (Addley 2015), a nightclub bouncer or boxer (Barber and Hope 2015), or a shaven headed, fitness addict and sex symbol whose female fans are called "Varoufitses" (Christides 2015). Minister Varoufakis would often meet his counterparts (dressed in suits and ties) in Europe's capitals and in the halls of the EU institutions wearing an untucked, open-necked shirt under a leather jacket, and these differences in personal appearance were often depicted in the media as reflecting the contested nature of the meetings themselves as well as the agenda at stake.

Varoufakis' tenure as finance minister ended soon after the bailout referendum held in Greece on 5 July 2015 over disagreements concerning the terms of the agreement with Greece's creditors with Prime Minister Tsipras, who decided to agree to the conditions of the troika that were the basis for the third bailout agreement passed on Greece's parliament on 14 July 2015. Varoufakis did run as a candidate in the snap elections held later that same year, but instead decided to focus on creating a Europe-wide, left-wing political network titled Democracy in Europe Movement - or DiEM- that was launched on 9 February $2015,{ }^{12}$ with which he shifted his political actions from the national to transnational (European) level.

12 For more on DiEM, see http://www.diem25.org and https://tendancecoatesy.wordpress.com/2016/02/10/ yanis-varoufakis-diem25-launched-in-berlin-europe-will-be-democratised-or-it-will-disintegrate/. 


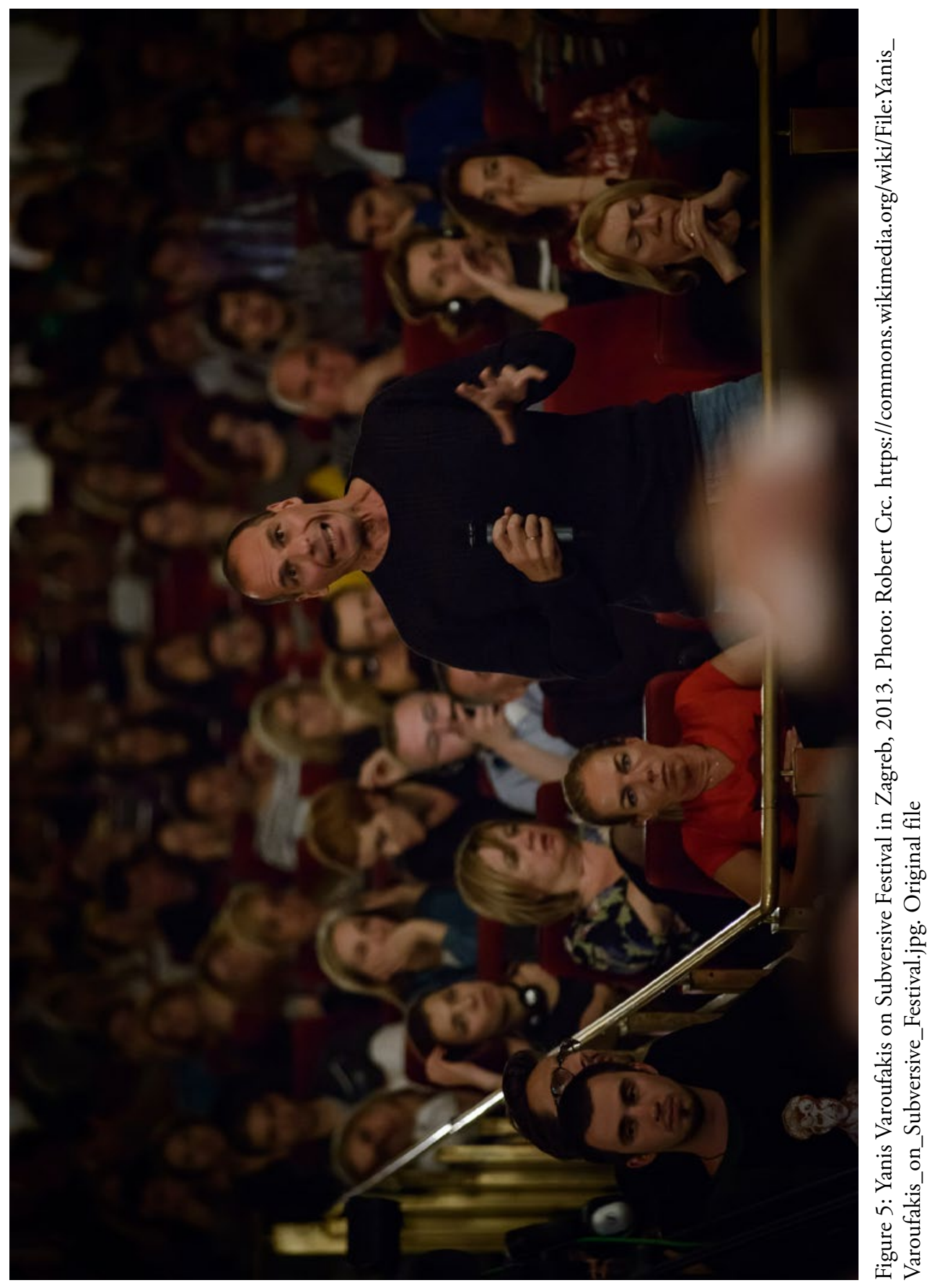




\section{CONCLUDING DISCUSSION ON THE CONSTRUCTION OF ECONOMIC CELEBRITY}

Journalists at The Economist compiled a ranking system to determine who are the world's most influential economists. They argued that economists are increasingly becoming part of important public debates, and that their visibility in the public sphere is not necessarily captured by the ranking criteria that economists employ among themselves, which include primarily the number and quality of publications and citations. Do economists who carry weight within their community of expertise also have the same sort of stature outside the boundaries of the community? Does this sort of status translate across social borders? Or is influence understood in terms of public presence defined differently across contexts? The alternative ranking system developed for The Economist demonstrated that, unsurprisingly, while a small number of well-known economists had both high numbers of academic citations and high levels of exposure in the public media, academic citations as an indicator of rank within a community of expertise do not necessarily imply a strong media presence outside it (The Economist 2015).

Writers of the article explained that the algorithm developed for the article was to calculate the amount of attention paid to economists' comments in diverse mainstream media during a 90-day period; however, it became apparent that the algorithm could not distinguish between different kinds of attention paid to comments. Evidence of this was the fact that economist Johnathan Gruber - who was at the center of an intense media controversy in the US in late 2014 about his comments on the US health-care law - was ranked most influential, far ahead of the rest of his colleagues. They were otherwise much more well-known public figures but were not at the forefront of the media during the chosen time period, during which the US health-care law figured as one of the major issues.

The fact that Johnathan Gruber - albeit an expert in his own right, but decidedly different from the elite economists who were listed at the top of the list - was ranked first was meant to exemplify the disparity between academic/economic prestige and media influence. And to a great degree this is so: only one or two economists who can be found among the top academic economists ranked comparatively high on the list of influential economists, with celebrity economist Paul Krugman being one of them. However, I would argue that the supposed anomaly of Johnathan Gruber is due more to the disparities between media presence and media influence and the way that this distinction also informs understandings of celebrity. While the list is presented as calibrating and ranking the influence of economists in the media, it in fact measures their media presence, and only in a limited manner. The world beyond the boundaries of communities of expertise that is often referred to as the public sphere is diverse and is multi-dimensional, rendering it difficult to quantify with a single ranking system or with a single algorithm, no matter how complex.

Setting aside the issue of conflating media presence and media influence, any single indicator for measuring media presence can offer only limited information about economists' 
celebrity understood simply as media presence or visibility within such an inherently heterogenous public sphere - including the number of Twitter followers, which was used the article mentioned earlier written by The Economist concerning Argentine celebrity economists. Among the celebrity economists discussed in this article, Paul Krugman ranks highest, with little over 1,500,000 Twitter followers, followed by Yanis Varoufakis, who has almost 700,000 followers. Jeffrey Sachs ranks last with almost 210,000 followers. The strong variation in number of followers may not reflect correspondingly diverse levels of popularity or influence but instead the extent to which any one indicator is useful for comparing different profiles of celebrity economists. Among which publics do these economists operate as celebrities?

Looking over these figures, it is not surprising that Paul Krugman has amassed such high number of followers given that his main activity as a celebrity economist/public intellectual is writing pieces as a syndicated columnist for a public medium with global reach and with an established foothold in the internet. Yanis Varoufakis' works do not appear so systematically in these forms of public media; the medium in which he disseminated his thoughts is the internet, more specifically, his website, through which he has cultivated a very strong presence. Jeffrey Sachs's relatively low number Twitter followers may seem surprising at first, particularly given he is a prolific writer and such a household name. However, I would argue that his celebrity is configured differently and his distinctive feature as a celebrity economist lies in the amount of his social capital he exercises through his links to varied powerful political and social networks when he seeks to attract attention for the causes he advocates.

I argue that the profiles that have been mapped out here can provide useful points of comparison and contrast that can aid one in better understanding the existing range of celebrity economists, their practices and their significance within the broader social sphere. The celebrity economists discussed above operate primarily as individual social actors as opposed to representatives or leaders of institutions. All four of them were educated in Western universities and have developed strong areas of expertise within economics; three of them have studied and/or working at elite US universities - Harvard, Yale, MIT, Princeton, Columbia - which also distinguishes them as elite actors within the economics as a global community of knowledge. They all - at one point or another - worked in university economics departments and thus in the production and reproduction of economic knowledge. However, none of them are advocates of the leading economic paradigm, i.e., the Washington Consensus (Williamson 1990) that advocates neoliberal, free-market policies. ${ }^{13}$

13 This is the case even for Jeffrey Sachs, who, while he advocated austerity measures and certain free-market reforms in transition countries, called for the pardoning of countries' foreign debt and thus worked primarily outside of the development establishment. This does not necessarily overlap with the prevalent image of Sachs among critics of neoliberalism, who characterize him as one of the most visible proponents of the Washington Consensus (see Klein 2007). 
Another very important feature that links these economists is the prevalence of upheaval as the backdrop against which they operate - both as economists and as celebrities in the public sphere. Yanis Varoufakis made a comment similar to that of economics professor Victoria Garrizo that was cited at the beginning of the article, who argued that Argentine economists' popularity was inversely related to the state of Argentina's economy. When asked about the reasons why economists have become such large media figures, Varoufakis succinctly replied: "When there is an earthquake seismologists become important. Now we have an economic crisis, economists are important" (The Guardian 2015). While I questioned the truth-value of this sort of statement earlier, arguing that it presented economists' own view of themselves and the belief in their own expertise, there is also some truth to this statement. The economic crisis whose repercussions are felt across the globe surely informs the rise of economists' presence in the public sphere and their celebrity, but not necessarily of their influence understood in traditional terms. Their celebrity understood as presence in the public sphere does not necessarily translate into importance understood as influence or power to shape economic policy, which is what economists themselves presume when conflating the concepts of media presence and media influence/importance. Instead, it is necessary to examine the range of formulations of economists' celebrity in the field of practice to later begin mapping out the social role of celebrity economists both as celebrities and as economists.

The celebrity economists discussed above have worked in diverse contexts that can be described as crisis situations that operate as frames of contested discussion in which economists are depicted as providing insights and even solutions to complex problems. As is apparent from the different profiles discussed above, these depictions can take different forms. The heightened tensions that accompany the contested terrain of public debate on economic policies in a crisis situation imply that their public personas are more polarized in nature due to the controversy that often accompanies them. The contested nature of their celebrity is to some extent a result of their own actions and practices in cultivating their public persona. However, the media also plays an important role by highlighting certain features of a celebrity, and this selection is often linked to the particular context in which a celebrity economist operates, the terms of discussion, and the remaining actors that comprise the landscape of contestation.

In such contexts, celebrity economists operate as ambiguous and controversial social actors, whose range of activities and public images are depicted in very different ways. At the most basic level, this is due to the fact that the roots of celebrity economists' social prestige are inherently diverse. On the one hand, they all are recognized as experts in their fields of expertise within economics, whether this be trade theory, hyperinflation, or game theory. These forms of expertise also operate as platforms for their operation outside their field of knowledge (and thus outside the world of the production and reproduction of economic knowledge) and the boundaries that delimit economics as a community of expertise. However, their public persona beyond the sphere of their community of knowledge 
are often defined by the role that they play in the controversies in which they take part, and their celebrity results in their being ascribed new forms of identity beyond that of expert - forms of identity that are to a great extent shaped by the interactions in which they engage as economists in the broader public sphere. In this manner, Paul Krugman is known as a polemicist, both loved and hated due to his widely read, often provocative columns; Jeffrey Sachs is known as a doctor due to his radical plans of reform and a guru to celebrity advocates; and Yanis Varoufakis is known as the debunker of austerity plans.

Another important reason for these actors' controversial and ambiguous nature is that their role outside their community of knowledge is not limited to celebrity understood in the narrow sense of the word. Returning to Boorstin's definition of celebrity as a person known for being famous (Boorstin 1992), these social actors are not only well known for being famous but for the social significance that is accorded to their actions outside their community of knowledge: be it operating as a public intellectual, an international consultant or a finance minister. Their practices within a heightened, contested context of crisis and debate and their operations from diverse social and economic positions accord them celebrity as well as varying levels of social, political and economic power, all of which are conflated when they are considered solely as celebrities. It is necessary to thus approach celebrity economists in a more integral manner, which implies identifying and distinguishing the different kinds of social capital, prestige and influence with which celebrity economists operate as social actors in order to identify and analyze the inherently nuanced role that they play in the public sphere in terms of discourse and action. Distinguishing the varied yet interconnected roles that they play will entail mapping out additional networks in which they operate and identifying relevant social actors who are also - albeit indirectly - involved in the production of economists' celebrity or have a vested interest in it. Such an approach raises a very pertinent question in times of economic crisis, when complex issues and problems in the media run the risk of being reduced to an interplay between diverse economic personalities. In addition, it will enable further research into the formation of celebrity economists and their activities as public social actors as well as the broader significance of their operations in the global public sphere. 


\section{REFERENCES}

2008. „Irving Fisher.“ The Concise Encyclopedia of Economics. Library of Economics and Liberty. 22 January 2016. <http://www.econlib.org/library/Enc/bios/Fisher.html>

Addley, Esther. 2015. Stories of 2015: Yanis Varoufakis, Greece's anti-austerity motorbiker. The Guardian. 24.12.2015. http://www.theguardian.com/world/2015/dec/24/ stories-2015-yanis-varoufakis-syrizas-anti-austerity-motorbiker

Andrews, D.L. and Jackson, S.J. eds. 2001. Sports Stars: The Cultural Politics of Sporting Celebrity. London and New York: Routledge.

Barber, Tom and Kerin Hope. 2015. Yanis Varoufakis, Greek Finance Minister. Financial Times. 06.02.2015. http://www.ft.com/intl/cms/s/0/e449635a-ad3a-11e4-a5c1-00144feab7de.html\#axzz3zJ9mhXGM

Boorstin, Daniel J. 1992 (1961). The Image: A Guide to Pseudo-Events in America. New York: Vintage Books.

Brockington, Dan. 2015. Celebrity Advocacy: International and Comparative Perspectives, Celebrity Studies, 6 (4): 393-398, DOI: $10.1080 / 19392397.2015 .1087205$

Cassidy, John. 2005. Always with Us? Jeffrey Sachs's Plan to Eradicate World Poverty. 11.04.2005. http:// www.newyorker.com/magazine/2005/04/11/always-with-us

Couldry, Nick. 2009. “The Media”: A Crisis of Appearances. McMaster University Globalization Working Papers, 09-03. https://socialsciences.mcmaster.ca/institute-on-globalization-and-the-human-condition/documents/IGHC-WPS_09-03_Couldry.pdf

Christides, Giorgos. 2015. Profile: Yanis Varoufakis, Greek Bailout Foe. BBC News 6 July 2015. http:// www.bbc.vcom/news/world-europe-31452402.

Dežman, Jože. 2013. Heroji vojne in revolucije. In Heroji in slavne osebnosti na Slovenskem, ed. Božidar Jezernik, 115-135. Ljubljana: Znanstvena založba Filozofske fakultete.

Dimand, Roger W. and John Geanokoplos. eds. 2005. Celebrating Irving Fisher: The Legacy of a Great Economist. London: Blackwell.

Driessens, Olivier. 2013. The celebritization of society and culture: Understanding the structural dynamics of celebrity culture. International Journal of Cultural Studies 16 (6): 641-657. DOI: 10.1515/2014-0008

Dyer, Richard. 1979/2001. Stars. London: BFI Publishing.

Dyer, Richard. 1986. Heavenly Bodies: Film Stars and Society. London: Routledge.

Easterly, William. 2006. The White Man's Burden: Why the West's Efforts to Aid the Rest Have Done so Much Ill and So Little Good. New York: Penguin Books.

Epstein, Joseph. 2005. Celebrity Culture. Hedgehog Review 7.1 (2005): 7-20. http://iasc-culture.org/THR/ archives/Celebrity/7.1CEpstein.pdf

Fikfak, Jurij. 2014. Heroes, Leaders of Nations. Traditiones 43 (1): 7-11. DOI: 10.3986/Traditio2014430101

Fisher, Irving. 1924. Does Tobacco Injure the Human Body? Readers Digest pp. 435-436.

Gamson, Joshua. 1994. Claims to Fame: Celebrity in Contemporary America. Berkeley, CA: University of California Press.

The Guardian. 2015. Brian Eno Meets Yanis Varoufakis: «Economists are more Showbiz than Pop Stars Now». 28.11.2015. http://www.theguardian.com/lifeandstyle/2015/nov/28/ conversation-brian-eno-yanis-varoufakis-interview 
Hill, Annette. 2007. Restyling Factual TV: Audiences and News, Documentary and Reality Genres. London and New York: Routledge.

Holmes, Su. 2008. Entertaining Television: the BBC and Popular Television Culture in the 1950s. Manchester: Manchester University Press.

Holmes, Su and Sean Redmond. 2006. Framing Celebrity: New Directions in Celebrity Culture. London and New York: Routledge.

Hudales, Jože. 2013. Rudarji so junaki, zmagoslavcki v bitki vsaki: Junaki socialističnega dela in udarništvo Velenje. In Heroji in slavne osebnosti na Slovenskem, ed. Božidar Jezernik,89-114. Ljubljana: Znanstvena založba Filozofske fakultete.

Inglis, Fred. 2000. A Short History of Celebrity. Princeton: Princeton University Press.

Jezernik, Božidar. 2013. Veliki možje in razvoj slovenskega narodnega vprašanja. In Heroji in slavne osebnosti na Slovenskem, ed. Božidar Jezernik,7-25. Ljubljana: Znanstvena založba Filozofske fakultete.

Kellner, Douglas. 2010. Celebrity Diplomacy, Spectacle and Barack Obama. Celebrity Studies 1:1, 121-123, DOI: $10.1080 / 19392390903519156$.

Klein, Naomi. 2007. The Shock Doctrine: The Rise of Disaster Capitalism.

Komel, Dean. 2014. Jože Pučnik: Personal Freedom, Culture and Politics. Traditiones 43 (1): 125-135. DOI: 10.3986/Traditio2014430109

Kotler, Philip, Irving J. Rein and Martin R. Stoller. 1997. High Visibility: the Making and Marketing of Professionals into Celebrities. McGraw-Hill Contemporary.

Kovač, Stanislav. 2010. Public Enemy: Jože Mencinger je veliki privatizacijski krivičnez. Finance. (22-12-2010). http://www.finance.si/298257/Public-enemy-Jože-Mencinger-je-veliki-privatizacijski-krivičnež?̌cctest\&

Krugman, Paul. 1994. The Age of Diminished Expectations: U.S. Economic Policy in the 1990s. London and Cambridge: MIT Press.

MacFaquihar, Larissa. 2010. The Deflationist: How Paul Krugman Found Politics. The New Yorker (March 1, 2010). http://www.newyorker.com/magazine/2010/03/01/the-deflationist

Mackenzie, James. 2015. Profile: Greek Finance Minister Yanis Varoufakis. Reuters. accessed 15 March 2016. http://www.reuters.com/article/finmin-gr-idUSL6N0V742820150128

Marshall, P. David. 2010. The Promotion and Presentation of the Self: Celebrity as a Marker of Presentational Media. Celebrity Studies 1(1): 35-48. DOI: 10.1080/19392390903519057

Mencinger, Jože.2008. Chicago Boys in Slovenija. Mladina (13.1.2008). http://www.mladina.si/97220/ chicago-boys-in-slovenija/

McDonald, M.G. and Andrews, D.L., 2001. Michael Jordan: Corporate Sport and Postmodern Celebrityhood. In: D.L. Andrews and S.J. Jackson, eds. Sports Stars: the Cultural Politics of Sporting Celebrity. London and New York: Routledge, 20-35.

Munk, Nina. 2007. Jeffrey Sachs's \$200 Billion Dream. Vanity Fair. July 2007. http://www.vanityfair.com/ news/2007/07/sachs 200707

Munk, Nina. 2013. The Idealist: Jeffrey Sachs and the Quest to End Poverty. New York: Doubleday

Murray, Susan. 2005. Hitch Your Antenna to the Stars: Early Television and Broadcast Stardom. London: Routledge.

Muršič, Rajko. 2013. Pomembneži v Sloveniji: velmožje in zvezde v slovenski znanosti in popularni glasbi. In Heroji in slavne osebnosti na Slovenskem, ed. Božidar Jezernik, 137-149. Ljubljana: Znanstvena založba Filozofske fakultete. 
Neary, J. Peter. 2009. „Putting the, New into New Trade Theory: Paul Krugman's Nobel Memorial Prize in Economics“. Scandinavian Journal of Economics 111 (2):217-250. doi:10.1111/j.1467-9442.2009.01562.x.

Pletenac, Tomislav. 2014. From Conviction to Heroism: The Case of a Croatian War General. Traditiones 43 (1): 111-123. DOI: 10.3986/Traditio2014430108

Podjed, Dan. 2012. Slovenske instant zvezde: Ustvarjanje in ohranjanje slave po svetovnem spletu. Glasnik Slovenskega etnološkega društva 52(1/4): 72-81.

Ponce de Leon, Charles L. 2002. Self-Exposure: Human Interest Journalism and the Emergence of Celebrity in America 1890-1940. Chapel Hill: University of North Carolina Press

Read, Colin. 2012. Irving Fisher, the First Celebrity Finance Professor. Bloomberg View. http://www.bloombergview.com/articles/2012-11-27/irving-fisher-the-first-celebrity-finance-professor

Risen, James. 1990. Cowboy of Poland's Economy: Ah, to be 35, American and Solidarity's Most Influential Advisor: Jeffrey Sachs and his Critics Alike Agree it's Downright Scary. Los Angeles Times. 09 February 1990. http://articles.latimes.com/print/1990-02-09/news/mn-248_1_jeffrey-sachs

Rojek, Chris. 2001. Celebrity. London: Reaktion Books.

Sachs, Jeffrey D. 2005. The End of Poverty: Economic Possibilities for Our Time. New York: Penguin Press.

Schumpeter, Joseph (1951). Ten Great Economistsfrom Marx to Keynes. New York: Oxford University Press.

Tobin, James. 2005. Irving Fisher (1867-1947). American Journal of Economics and Sociology 64 (1): 19-42. DOI: $10.1111 /$ j.1536-7150.2005.00347.x

Tomasky, Michael. 2007. The Partisan. The New York Review of Books, November 22, 2007, http://www. nybooks.com/articles/2007/11/22/the-partisan/

Turkoz, Meltem. 2014. Fathering the Nation: From Mustafa Kemal to Atatürk. Traditiones 43 (1): 53-64. doi: 10.3986/Traditio2014430105

Turner, Graeme, Frances Bonner and P. David Marshall. 2000. Fame Games: the Production of Celebrity in Australia. Melbourne: Cambridge University Press.

Varoufakis, Yanis, Stuart Holland and James K. Galbraith. 2010. Modest Proposal.. https://yanisvaroufakis. eu/euro-crisis/modest-proposal/

Varoufakis, Yanis. 2011. The Global Minotaur: America, the True Causes of the Financial Crisis and the Future of the World Economy. London and New York: Z Books.

Varoufakis, Yanis, Joseph Halevi and Nicholas Theocarakis. 2011. Modern Political Economics: Making Sense of the Post-2008 World. London and New York: Routledge

Whannel, Gary. 2001. Media Sports Stars: Masculinities and Moralities. London: Routledge Press.

White, Martin L. 2016. Thomas Picketty: French Economist. Encyclopedia Britannica. accessed 22 January 2016. http://www.britannica.com/biography/Thomas-Piketty

Williamson, John. 1990. What Washington Means by Policy Reform. In. John Williamson, ed. Latin American Adjustment: How Much Has Happened? Washington, DC: Peterson Institute for International Economics. http://www.iie.com/publications/papers/paper.cfm?researchid=486.

Zupan Sosič, Alojzija. 2013. Heroji in herojinje v sodobnem slovenskem romanu. In Heroji in slavne osebnosti na Slovenskem, ed. Božidar Jezernik,213-228. Ljubljana: Znanstvena založba Filozofske fakultete. 


\section{EKSPERTI, POLEMIKI, ZDRAVNIKI IN RAZKRINKOVALCI TIPOLOGIJA SLAVNIH EKONOMISTOV}

Analiza se osredinja na slavne ali zvezdniške ekonomiste kot posebno skupino slavnih oseb oz. zvezd, ki jih je mogoče najti vstevilnih družbah in kulturah v sodobnem svetu. Ekonomistom, tj. nosilcem in praktikantom privilegirane znanstvene vede, se na splošno pripisuje razmeroma visok družbeni in strokovni ugled oz. prestiž. Kazalniki vrednosti, ki so pripisani oz. povezani z ekonomijo, so številni in raznovrstni: v vsakdanjem jeziku se utrjuje vedno več izrazov iz ekonomskega strokovnega žargona; prevladuje prepričanje, da je gospodarstvo gonilna sila družbenih sprememb; naposled je pomen ekonomije razviden tudi iz daljnosežnih posledic problemov v gospodarstvu.

Ekonomija ni zgolj teoretična disciplina, ki se razvija le v slonokoščenih stolpih univerz in akademij; njeni strokovnjaki oz. praktiki imajo pomembne vloge $v$ državnih organih in ustanovah, dejavni so $v$ dnevnem delovanju trgov na vseh ravneh. Zaradi tega ni presenetljivo, da so nekateri ekonomisti pri svojem delu ne le prekoračili meje svoje strokovne skupnosti, ampak so postali poznani v širšem javnem življenju. Med njimi so tudi takšni, ki so postali tako poznani zunaj svoje stroke, da jih labko opredelimo kot slavne ali zvezdniške ekonomiste, katerih imena pozna vsakdo.

Vendar pa vseh ekonomistov ni mogoče portretirati z istim čopičem. Na svetu so številni slavni in celo zvezdniški ekonomisti, vendar njihov ugled labko temelji na različnih dejstvih: na izjemni znanstveni karieri, raziskovalnem prispevku, labko se odlikujejo kot pomembni intelektualci, kot politiki ali kot izredni strokovnjaki in praktiki pri konkretnem delu. Da bi sistematičneje preučila razpon njihovih praks in javnih podob, $v$ etnografski analizi avtorica predstavlja svojo raziskavo o slavnih ekonomistih kot družbeni kategoriji v različnih sodobnih družbah.

Dr. Tatiana Bajuk Senčar, Institute of Slovenian Ethnology, Research Center of Slovenian Academy of Sciences and Arts, Novi trg 2, SI-1000 Ljubljana, tatiana.bajuk@zrc-sazu.si 